\title{
Population assessment and foraging ecology of nest aggregations of the rare solitary bee, Eucera longicornis at Gatwick Airport, and implications for their management
}

\author{
Georgia Hennessy $^{1}\left[\right.$ D . Dave Goulson ${ }^{1} \cdot$ Francis L. W. Ratnieks ${ }^{1}$
}

Received: 7 May 2020 / Accepted: 18 August 2020 / Published online: 27 August 2020

(c) The Author(s) 2020

\begin{abstract}
Eucera longicornis is a rare solitary bee that is in decline throughout its range in Britain and other European countries. Two nest aggregations that had been previously discovered in 2014 on land owned and managed by Gatwick Airport, Southern England, were studied in 2017, 2018 and 2019 to obtain information relevant to their conservation. Population estimates using mark recapture showed that the larger aggregation had a maximum population estimate of 659 individuals in 2018, with the smaller aggregation reaching a maximum population estimate of 221 in 2019. In terms of foraging requirements, microscopic analysis of pollen samples from females returning from their nests identified a total of 12 plant taxa across all years and both aggregations. Fabaceae pollen was present in $100 \%$ of samples and on average comprised $90 \%$ of each sample, indicating that the species is oligolectic. Both nest aggregations were on sloping banks of exposed soil arising from land management by the airport in 1999. Floral surveys of the landscape indicate that within $100 \mathrm{~m}$ of both aggregations Fabaceae species are the most abundant due to the presence of a legume rich wildflower meadow alongside the adjacent river Mole, which was sown by Gatwick Airport. Eucera longicornis at Gatwick Airport are an example of how if managed appropriately, industrial areas can provide valuable refuges for rare wildlife. Although there is no imminent risk of the populations going extinct, management and monitoring suggestions are provided to ensure these populations persist.
\end{abstract}

Keywords Conservation $\cdot$ Solitary bee $\cdot$ Foraging ecology $\cdot$ Population ecology $\cdot$ Ecology

\section{Introduction}

Although the extent to which global insect declines are occurring is currently debated (Thomas et al. 2019), there is no doubt that at many local scales some insect species are in decline (Didham et al. 2020). More monitoring and research on population abundance is required to fully understand the state of the world's insects (Montgomery et al. 2020). Examples of national declines include butterflies in the Netherlands, with 55\% of common species suffering both declines in abundance and distribution between 1992 and

Electronic supplementary material The online version of this article (https://doi.org/10.1007/s10841-020-00266-8) contains supplementary material, which is available to authorized users.

Georgia Hennessy

g.i.hennessy@sussex.ac.uk

1 School of Life Sciences, University of Sussex, Falmer, East Sussex, Brighton BN1 9QG, UK
2007 (Van Dyck et al. 2009). In the UK, 34/46 butterfly species declined in distribution area between 1970 and 1999 (Warren et al. 2001).

Bumblebees, one of the best documented and most studied insect groups, have suffered ongoing losses in diversity in the UK (Goulson et al. 2008) and Europe (Rasmont et al. 2015). However, bumblebees are not the only groups of bees at risk. Between 1980 and 2013, solitary bees suffered an average 32\% reduction in range (Powney et al. 2019). In the UK, 23 bee and flower visiting wasp species have gone extinct since the late 1800 s, with only two of these being bumblebee species (Ollerton et al. 2014). For many solitary bee species, changes in landscape structure can be hugely detrimental as they often have specialised nesting, (Westrich 1996; Wcislo and Cane 1996; Zurbuchen et al. 2010a, b) and forage requirements (Westrich 1996; Wood et al. 2017) alongside limited foraging ranges (Gathmann and Tscharntke 2002; Greenleaf et al. 2007).

Some of the main drivers identified as contributing to insect declines are urbanisation and habitat loss due to 
agricultural intensification (Leather 2017). Despite covering a small area of the globe $(\sim 2 \%$, Svirejeva-Hopkins et al. 2004) urban landscapes have had detrimental effects on some insect species. For example, in a study examining bees and wasps in Belo Horizonte, Brazil, the abundance of stingless bees was negatively affected by the increase of buildings and loss of vegetation cover associated with urbanisation (Zanette et al. 2005) and a study using allotments in the inner city of Stockholm found bumblebee diversity decreased with increasing urbanisation (Ahrne et al. 2009).

However, in the Ahrne et al. (2009) study they also identified that allotments with rich flower diversity can serve as important alternatives to natural habitats for some bumblebee species. This is seen in other studies, with some species readily utilising urban landscapes. Banaszak-Cibicka and Zmihorski (2012) found that some social bee species that emerged later in the year (June-July) were higher in abundance in the city centre compared to the surrounding suburban area. In the UK, bee abundance did not to differ between urban, farmland and nature reserves, with bee species richness being higher in urban landscapes compared to farmland (Scriven et al. 2013; Baldock et al. 2015).

Some human-altered landscapes, such as brownfield sites, can become refuges for wildlife once abandoned. For example, in the UK, 194 invertebrate species of conservation importance have been recorded from brownfield sites. This includes $50 \%$ of rare solitary bees (Macadam and Bairner 2012).

Even in areas of semi-natural habitat where human disturbance is ongoing, management can be effective in maintaining, or even promoting, insect biodiversity. Areas under powerlines, for example, where regular clearing of forest must take place, were found to have a higher species richness and abundance of solitary bee species compared to areas of the same forest that have not been cleared (Steinert et al. 2020). Sand quarries can also be important habitats for many invertebrate species (Buglife 2009) including some nationally rare solitary bee species (e.g. Colletes cunicularis Formstone and Howe 2013). Sites often blamed for environmental damage, such as airports, can be managed in a way to promote insect biodiversity (Kutschbach-Brohl et al. 2010) and allow for the nesting of rare ground nesting birds (Kershner and Bollinger 1996). On semi-urban sites where rare species are located, it is important to conduct population monitoring and gain information on the specific ecological requirements of the species, to ensure the correct management scheme is conducted and effective (Kershner and Bollinger 1996).

Eucera longicornis, the long -horned bee, is a rare solitary bee that is a nationally declining species in the UK and is listed as a BAP priority species (JNCC 2007). It used to be widespread in England and Wales and was present in most of the counties south of Oxfordshire, with old records reporting individuals as far north as Yorkshire (Falk and Lewington 2015). It is now restricted to mainly southern sites, predominately coastal with a few inland populations as far north as Shropshire (Fig. 1).

In 2014 E. longicornis was found to be nesting in a human-altered landscape on land owned and managed by Gatwick Airport by Rachel Bicker, the airports biodiversity officer, in 2014 (Rachel Bicker, pers comms). There are two nest aggregations. One in a man -made soil heap approximately $200 \mathrm{~m}$ from the runway, and the other roughly $1 \mathrm{~km}$ north along the bank of the river Mole. Both are on land owned and managed by Gatwick Airport but outside the airport perimeter fence.

The Gatwick Airport E. longicornis are the subject of this investigation. The aims are to determine key information about the Gatwick population that could be used as a baseline for population monitoring and to provide information relevant to conservation. We determined the population size of each aggregation using mark recapture. We also determined the main forage sources through pollen analysis and surveyed floral resources in the surrounding landscape.

\section{Methods}

\section{Study organism}

Eucera longicornis is a medium sized solitary bee (fore wing length $9-10.5 \mathrm{~mm}$, Falk and Lewington 2015), the females

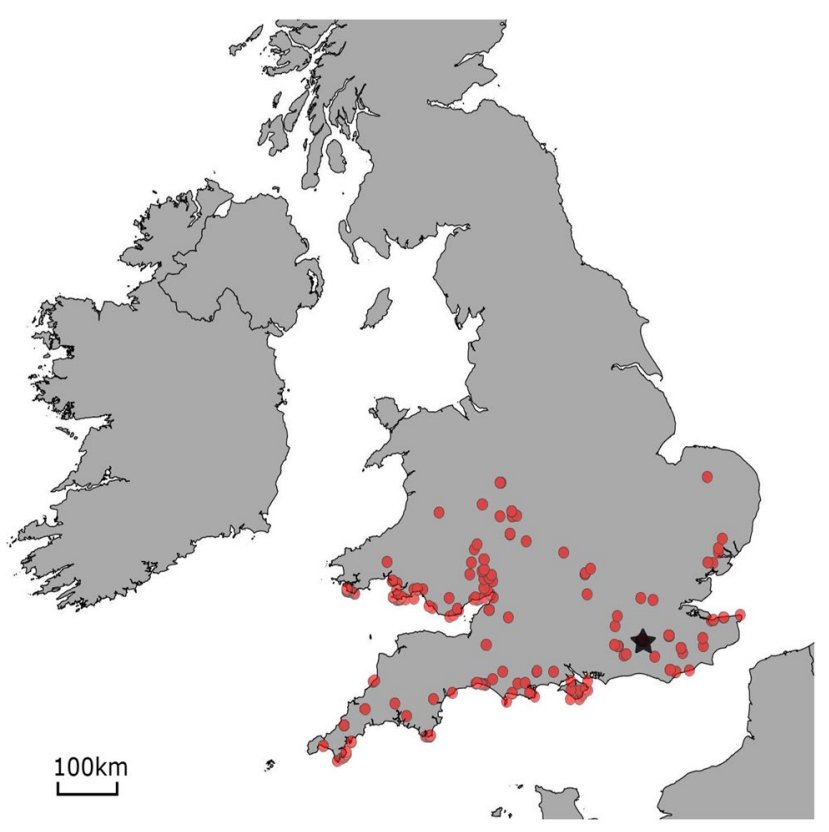

Fig. 1 Current distribution of E. longicornis in the UK taken from the NBN atlas. The black star indicates Gatwick Airport, where this study takes place 
slightly larger than the males. Males have the distinctly long antennae which give the species its name (Fig. 2) and is unique in British bee species. E. longicornis is widespread throughout Eurasia, extending as far east as China (BWARS 2012). In the UK, adults emerge in May and are usually active until early July, sometimes extending into August. Females nest in the ground, normally in bare soil on south facing slopes in aggregations alongside other nesting females (Saunders 2014).

\section{Study site}

Two aggregations were identified in 2014 on land owned and managed by Gatwick Airport (Fig. 3) in West Sussex,
UK. In 1999, for flood management the nearby river Mole was diverted from the eastern side to the western side of a wood near the airport. Meanders were created to slow the flow and increase water retention within the floodplain. Raised areas were also created to divert water away from important infrastructure. Alongside the river wildflowers and legumes were seeded, resulting in a diverse and flower rich meadow. The work also resulted in a large amount of soil being taken from the river bed and piled into environmental bunds, which created slopes with scant vegetation cover. Natural erosion along the river bank also created areas of exposed soil.
Fig. 2 a Female E. longicornis with paint mark foraging on Lathyrus pratensis at study site; b Male E. longicornis foraging on Symphytum, showing the trademark long antennae
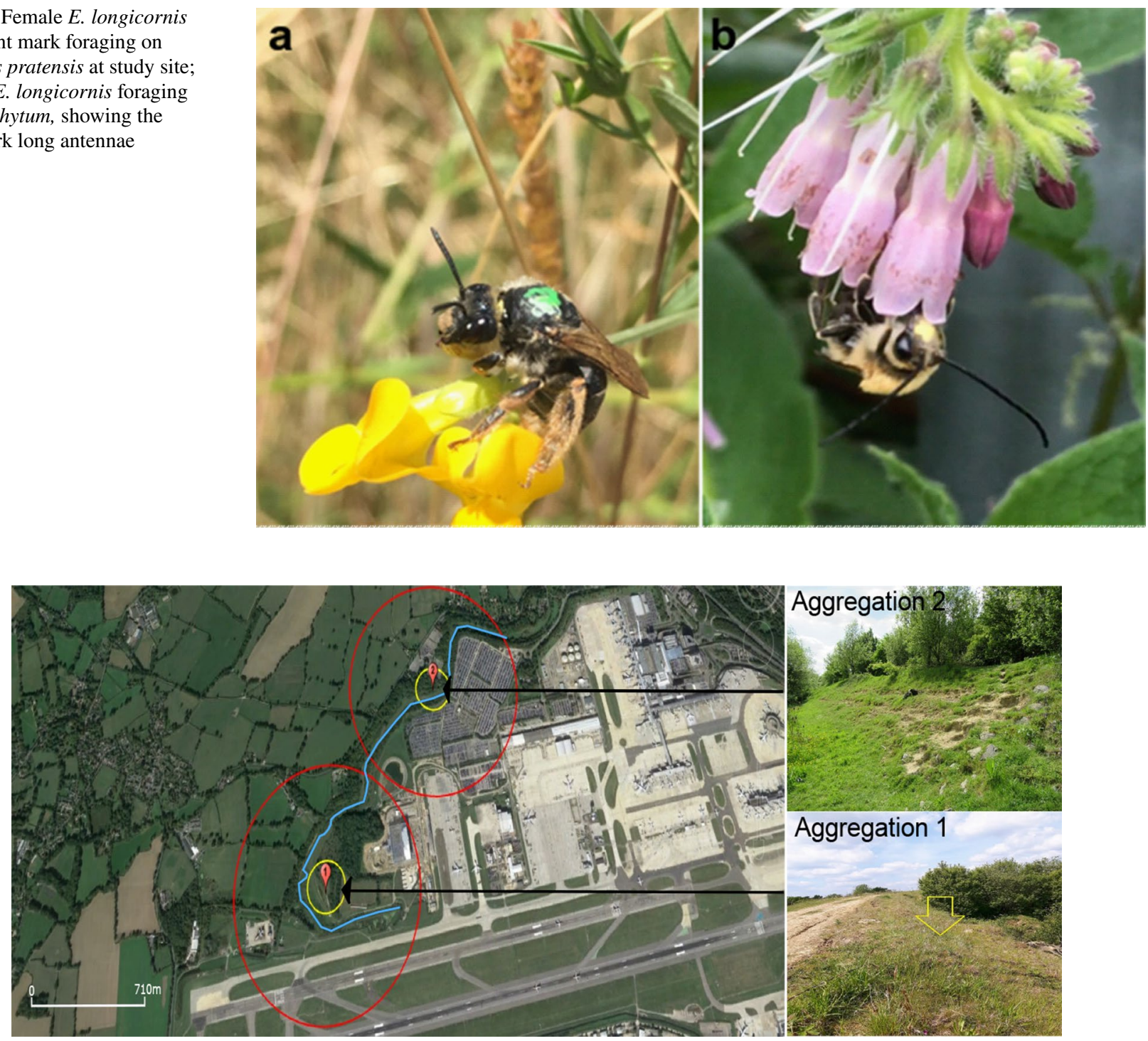

Fig. 3 Location of the two Gatwick Airport E. longicornis aggregations studied. The yellow inner circle shows $100 \mathrm{~m}$ from the centre of the aggregation, with the outer red circle showing $500 \mathrm{~m}$. The num- bers indicate the aggregation. The blue line represents the river Mole. Photos on the right are of the banks where the nest aggregations are located (Rachel Bicker pers comms.) 


\section{Aggregation 1}

The larger aggregation of E. longicornis is found along a slope about $200 \mathrm{~m}$ north from the airport runway, latitude 51.150603 longitude 0.20474334 (Fig. 3) and was first discovered in the spring of 2014. The aggregation is located on one of the steeply sloped mounds created in 1999 from soil excavated during the river Mole diversion. The mound is east facing, sparsely covered in short grass and bramble with patches of exposed soil (Fig. 3). The aggregation extends over an area of approximately $140 \mathrm{~m}^{2}$. The landscape within the surrounding $300 \mathrm{~m}$ contains manmade structures, such as the runway, but also woodland and a wildflower meadow.

\section{Aggregation 2}

The other aggregation is located on the opposite side of the river, approximately $1 \mathrm{~km}$ north east of aggregation 1 and backing onto Charlwood Park, grid reference latitude 51.159232 longitude -0.19627099 (Fig. 3). It too is on a steeply banked slope, sparsely covered in short grass with patches of exposed soil due to natural erosion from walkers, approximately $10 \mathrm{~m}$ from the river and facing south east (Fig. 3). In 2018, the second year of data collection, nests were seen approximately $20 \mathrm{~m}$ further along the bank to the west, in the direction of the airport. Due its proximity, it was considered to be part of aggregation 2 in both 2018 and 2019. In these years, the combined area containing nests was $120 \mathrm{~m}^{2}$, not including the gap between two nesting areas. The landscape within the surrounding $300 \mathrm{~m}$ is similar to aggregation 1, with meadow wildflowers and dense woodland and manmade structures consisting of a road and carpark.

\section{Population estimates using mark recapture}

Population estimates were made in 2017, 2018 and 2019 flight seasons using mark recapture. In 2017, data were collected in five study days per aggregation between 10 June and 1 July. In 2018 there were 8 study days, between 26 May and 11 July and in 2019 there were 10 study days between 21 May and 13 July. Field work took place only on days of good weather suitable for insect flight with temperatures from 17 to $30{ }^{\circ} \mathrm{C}$ and sunny. Due to intermittent weather, field work could not always occur at consistent time intervals. Bees were captured at the aggregation using an insect net, starting between 10:00 and 11:00 am and continued for $4 \mathrm{~h}$ to cover the peak foraging period. An observer would walk through the entire aggregation and capture any returning or departing females or patrolling males seen. When caught the bee would be transferred to a queen marking cage (Pixnor, China) and marked with an individual colour combination and pattern (Fig. 2) using non- toxic acrylic paint (Revell,
Germany). If the individual was a female carrying pollen, a small sample would be scraped from the scopa on each hind leg and placed in an Eppendorf tube for later analysis. Each sample was kept separate, and pollen was collected even if the female was a recapture. The bee would then be released.

\section{Pollen analysis}

From each sample $1 \mathrm{mg} \pm 0.01 \mathrm{mg}$ of pollen was mounted in glycerine jelly with basic fuchsin to stain the individual grains. Identification used a compound light microscope at $\times 200$ magnification. The total number of pollen grains per plant species in the field of vision were recorded. Counts were taken from five random points on the microscope slide. The proportions of each species per sample were then calculated. Where possible, pollen was identified to species level using a reference collection from pollen collected from plant species at the study site, alongside a pollen identification book (Sawyer and Pickard 1981). However, due to similarities between some species this was not always possible and instead would be identified to the lowest possible classification. For many Fabaceae this was to family level.

\section{Floral surveys}

In 2018, 4 floral surveys were conducted across the period of maximum female activity (on the 20 and 29 June, 4 and 10 July) to determine the availability of floral resources. The land within $500 \mathrm{~m}$ of each aggregation was categorised into the following vegetation types: managed grassland (land actively managed by humans and the vegetation is predominately grass); meadows (land minimally managed by humans, vegetation is predominantly tall grass with wild flowers); woodland (predominately trees); roadside verges (any land which falls directly beside a road). $500 \mathrm{~m}$ was chosen as it falls near the maximum foraging range of female $E$. longicornis (Saunders 2014) and so is a relevant indication of potential forage.

Using a $50 \times 50 \mathrm{~m}$ grid and stratified random sampling, $100 \mathrm{~m}$ transects in each vegetation type were made based on by the area of each land type (Table 1) and the number of replicate land type areas available (approximately 1 transect per $1.2 \mathrm{ha}$ ). Due to access limitation not all the surrounding vegetation could be sampled and, on some days, not all the $100 \mathrm{~m}$ transects could be completed. Along each transect, the number of inflorescences per species were estimated. From this the average number of inflorescences per species per $100 \mathrm{~m}$ was calculated both overall and per habitat type. If a foraging E. longicornis was seen during a transect it was caught, marked and the coordinates were recorded.

Within both 100 and $500 \mathrm{~m}$ of each nest aggregation the percentage cover of each habitat type was calculated using Google Earth Pro. Here an additional landscape type, 
Table 1 Area of accessible land of each habitat type for each aggregation and the number of $100 \mathrm{~m}$ transects per survey date

\begin{tabular}{lllllll}
\hline Aggregation & Vegetation type & Area (ha) & \multicolumn{2}{l}{ Number of transects } \\
\cline { 5 - 6 } & & & 20 June & 29 June & 04 July & 10 July \\
\hline 1 & Managed Land & 6.10 & 5 & 5 & 5 & 5 \\
1 & Woodland & 4.53 & 3 & 3 & 3 & 3 \\
1 & Meadow & 5.92 & 7 & 7 & 4 & 5 \\
2 & Managed land & 4.84 & 4 & 4 & 5 & 4 \\
2 & Woodland & 4.61 & 4 & 3 & 4 & 4 \\
2 & Meadow & 3.56 & 5 & 5 & 5 & 5 \\
2 & Roadside & 1.12 & 1 & 1 & 1 & 1 \\
\hline
\end{tabular}

manmade, was included. This consisted of areas that were predominately concrete and had very little vegetation. These areas were not included in the floral surveys as they were inaccessible (e.g. the airport runway) but also would have been devoid of flowers.

Additional surveys searching for other aggregations in the area were conducted. These occurred along the banks of river Mole over $1 \mathrm{~km}$ from aggregation 2 in both a north west and north easterly direction. Suitable sites (a slight slope covered in sparse vegetation) were examined for nest holes of appropriate size indicating nesting female E. longicornis or for returning females or patrolling males. Suitable banks nearby to aggregation 1 were also surveyed. These surveys occurred each year once at the beginning of the survey period to identify patrolling males and once again when females began to emerge. An additional survey also occurred in June 2020.

\section{Data analysis}

Mark-recapture analyses for each aggregation and sex were calculated using the program MARK which uses maximum likelihood models to estimate population parameters (Cooch and White 2004). Because the data covered most of the flight season population closure was not a reasonable assumption as individual births and deaths were likely. Therefore, the open population POPAN parameterisation was used to estimate population parameters. POPAN calculates the apparent survival rate $\varphi$, the probability of capture $\mathrm{P}$, and pent, the probability than an animal from the superpopulation enters the subpopulation (the individuals occurring in the study). Model assumptions were calculated using the programme RELEASE GOF (goodness of fit) within MARK. The most appropriate model was selected using Akaike Information Criterion corrected for small sample sizes (AICc, Burnham and Anderson 1998) testing whether time dependent (t) or constant (.) parameters were more appropriate for the population. To test if sex ratios were biased a binomial test was run on the number of males and females caught. To test if there was a difference in the proportions of species present in pollen samples a general linear model with a binomial and log link function was used. Statistical tests and graphs were created using R ( R core team 2017).

\section{Results}

\section{Population estimates}

Over all 3 years a total of 432 females were caught at aggregation 1 and 236 at aggregation 2. In 2018 and 2019, 199 males were caught at aggregation 1 and 68 at aggregation 2 (Tables S1 and S2, Supplementary Materials). No males were caught in 2017 because the survey started after their flight period.

To obtain population estimates separate models were run for each year and sex. Using goodness of fit testing, models that best fitted the data were chosen. The models used are shown in Supplementary Materials (Table S3). Aggregation 1 was estimated to have a larger population in all years and for both sexes (Table 2) and was highest in 2019 at 440 females and 92 males (Table 2). For aggregation 2, both female and male estimates were also highest in 2019 at 183 females and 55 males (Table 2).

For aggregation 1 female survival estimates (Phi) ranged between 0.91 and 0.98 . For males, the highest survival estimate was in 2018, with 0.93 compared to an estimate of 0.36 in 2019 (Table S4). For aggregation 2, female survival estimates ranged between 0.89 and 0.95. Again, for males the highest survival estimate was in 2018, with 0.92 , compared to an estimate of 0.79 in 2019.

Capture probabilities for females in aggregation 1 ranged from 0.22 to 0.30 and were consistent across sample days. For males it ranged between 0.09 and 0.72 and in 2018 was time dependent. For aggregation 2, female capture probability ranged between 0.25 and 0.55 and for males ranged between 0.21 and 0.79 .

The biggest change in population size were large increases from 2017 and 2018 for both aggregations (aggregation $1147 \%$, aggregation $2142 \%$ ). However, captures started much later in the flight season in 2017 compared to other years (Fig. 4). For both aggregations the male population 
Table 2 Gross mark-recapture population estimates for each year and sex calculated from MARK using the models described in Supplementary Materials with the sex ratio for that year calculated from the number of caught individuals. Total number of individuals caught for each year and sex are shown. There are no male estimates for 2017 as data collection began after their flight period

\begin{tabular}{|c|c|c|c|c|c|c|c|c|}
\hline Aggregation & Year & Sex & Total caught & $\begin{array}{l}\text { Total recap- } \\
\text { tures }\end{array}$ & Gross population & Standard Error & $\begin{array}{l}\text { Change between } \\
\text { years }(\%)\end{array}$ & $\begin{array}{l}\text { Sex Ratio } \\
\text { (M:F) }\end{array}$ \\
\hline \multirow[t]{5}{*}{1} & 2017 & $\mathrm{~F}$ & 53 & 14 & 57.8 & 10.37 & & - \\
\hline & & $\mathrm{F}$ & 116 & 19 & 379.5 & 81.5 & $147 \%$ & $1: 1.0$ \\
\hline & 2018 & M & 121 & 16 & 280.2 & 57.8 & - & \\
\hline & & $\mathrm{F}$ & 263 & 82 & 440.2 & 45.0 & $15 \%$ & $1: 3.4$ \\
\hline & 2019 & M & 78 & 22 & 91.6 & 12 & $-101 \%$ & \\
\hline \multirow[t]{5}{*}{2} & 2017 & $\mathrm{~F}$ & 23 & 7 & 24.5 & 5.7 & & - \\
\hline & & $\mathrm{F}$ & 106 & 34 & 145.7 & 20.2 & $142 \%$ & $1: 2.4$ \\
\hline & 2018 & M & 43 & 12 & 54.8 & 13.1 & - & \\
\hline & & $\mathrm{F}$ & 107 & 32 & 182.6 & 28.4 & $23 \%$ & \\
\hline & 2019 & M & 25 & 7 & 37.9 & 24.4 & $-37 \%$ & $1: 4.3$ \\
\hline
\end{tabular}

\section{Females}
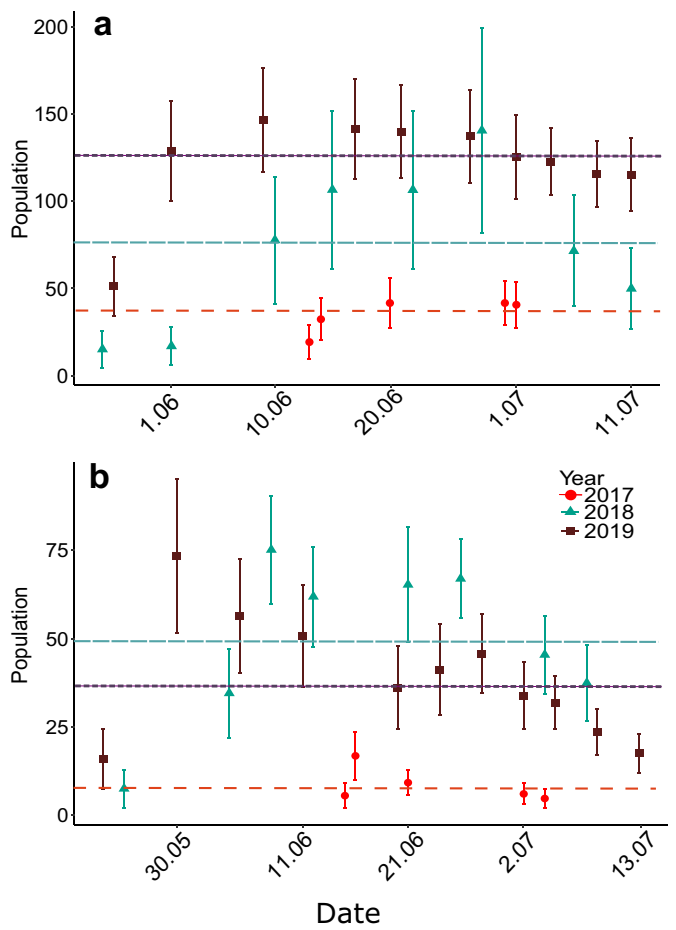

Fig. 4 Daily population estimates for females for all 3 years and males for 2018 and 2019 at both aggregations a females aggregation 1 , b females aggregation 2, $\mathbf{c}$ males aggregation 1, $\mathbf{d}$ males aggrega-

decreased between 2018 and 2019 (aggregation 1:-101\%, aggregation $2:-37 \%)$.

For aggregation 1, the sex ratio based on caught individuals did not differ from an expected 1:1 in 2018 (exact binomial test, $\mathrm{P}=0.79,1: 0.96)$. However, was female biased in 2019 (exact binomial test, $\mathrm{P}<0.001,1: 3.4$ ). For aggregation 2 sex ratios were female biased in both 2018 and 2019
Males
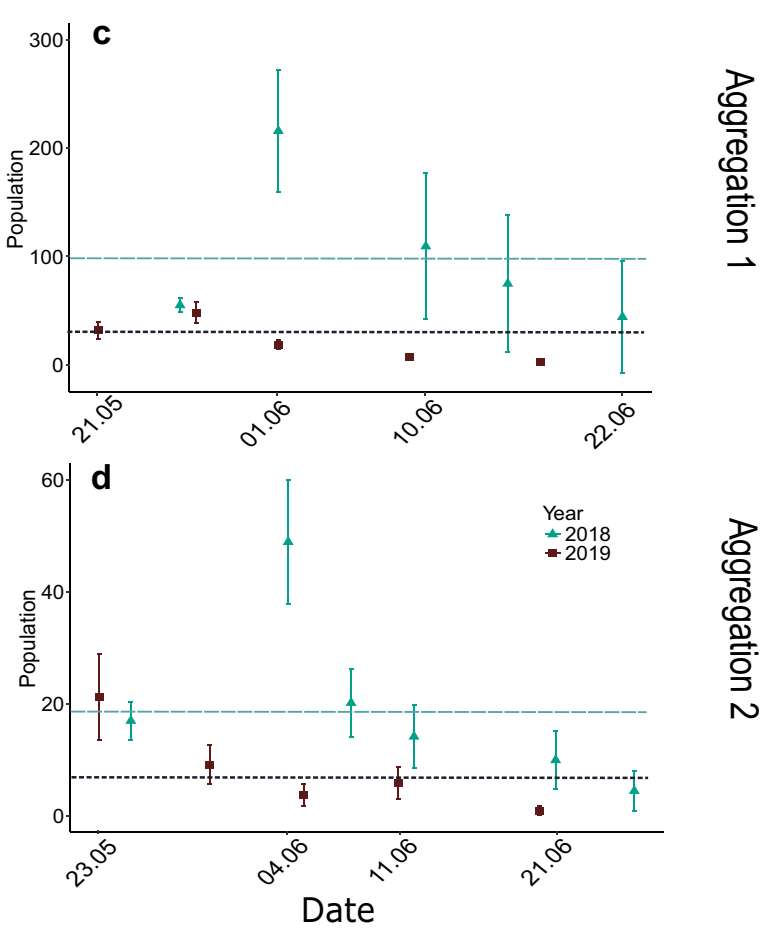

tion 2. Lines indicate the average daily population estimate and standard error bars are shown

(2018; exact binomial test, $\mathrm{P}<0.001,1: 2.4,2019$; exact binomial test, $\mathrm{P}<0.001$ 1:4.3, Table 2).

For both aggregations and all 3 years females reached their peak population estimate in mid -June (Fig. 4). For aggregation 1 the highest daily population estimate was in 2019 (122.4 $\pm 8.7,9$ June) versus 2018 for aggregation 2 (49.3 \pm 5.23 , 30 May Fig. 4). Males emerged earlier 
than females in 2018 and 2019 and at both aggregations (Fig. 4). For both aggregations male population peaked in late May and reduced throughout the survey period. Both daily population estimates were higher in 2018 than in 2019 (aggregation 1: $99.9 \pm 31.1$ vs $21.5 \pm 8.4$, aggregation $2: 19.1 \pm 6.4$ vs $8.2 \pm 3.5)$.

\section{Floral availability}

Floral availability was calculated from the mean percentage of inflorescences for each plant species or taxa present throughout the whole survey period. The mean percentage of each plant taxon was similar between aggregations (Fig. 5) but with Fabaceae species more abundant surrounding aggregation 1 . The most common plant species identified in surveys in aggregation 1 was Trifolium repens with an average of $195 \pm 39.1$ inflorescences per $100 \mathrm{~m}$ and an average of $18.0 \% \pm 5.25 \%$ of the total inflorescences surveyed. Vicia species and Lathyrus pratensis (meadow vetch) had a combined average of $90.7 \pm 28.2$ inflorescences per $100 \mathrm{~m}$. When grouped, all Fabaceae species (including Lotus corniculatus and Trifolium species) on average accounted for $44.3 \% \pm 7.20 \%$ of the inflorescences surveyed. A total of 39 non-Fabaceae species in bloom were identified in transects surrounding aggregation 1.

In aggregation 2, Vicia species and L. pratensis had a combined average of $145 \pm 59.4$ inflorescences per 100 m. All Fabaceae species comprised $13.1 \% \pm 12.3 \%$ of the surveyed inflorescences. The most common plant species identified in surveys in aggregation 2 was also $T$. repens, with $144 \pm 19.2$ inflorescences per $100 \mathrm{~m}$. A total of 47 non -Fabaceae species were identified surrounding aggregation 2 .

\section{Pollen samples}

Across the three sample years a total of 113 pollen samples were collected from female bees at aggregation 1 and 64 from aggregation 2. Fabaceae pollen was present in $100 \%$ of samples from both aggregations (Table 3). This included pollen from various Vicia, Lathyrus, Lotus and Trifolium species. Fabaceae pollen made up over $90 \%$ of the pollen grains in every sample for both aggregations (aggregation 1; 95.5 $\pm 0.75 \%$. aggregation 2; $94.6 \pm 0.89 \%$, Fig. 5). The remaining pollen grains were from seven species (Table 3) with bramble, $R$. fruticosus, the most common non- Fabaceae species (aggregation 1; 4.36 $\pm 0.98 \%$, aggregation $2 ; 5.44 \pm 0.66 \%$ ). Fabaceae pollen was present significantly more than other plant taxa in pollen samples from both aggregations (aggregation 1: general linear model, $\mathrm{F}_{1,230}=2137, \mathrm{P}<0.0001$; aggregation $2: \mathrm{F}_{1,132}=4370$, $\mathrm{P}<0.0001$ ). For aggregation 1 all samples contained pollen from more than one species. With aggregation 2, 97\% of samples contained pollen from more than one plant group. Two different unknown plant species were identified in samples from 2017 and 2019.

Pollen composition was similar between years. However, for aggregation 1 in 2019 pollen from seven plant groups not previously identified in samples was present (Table 3). For a breakdown of daily pollen proportions from samples see Supplementary Materials Figs. S1 and S2.

\section{Landscape composition}

Fabaceae species were most common in meadow habitat, with Vicia species and L. pratensis together averaging $208 \pm 35.9$ inflorescences per $100 \mathrm{~m}$ compared to 0 in woodland and managed grassland surrounding aggregation 1. For aggregation 2 the average per $100 \mathrm{~m}$ was double,
Fig. 5 Relative flower abundance and pollen collected. Mean percentages of inflorescences present over the whole survey period for the Fabaceae, the most common plant group identified in pollen, and all other species present in the survey area. Also shown are the average percentage of pollen from samples collected from females in 2018. a Aggregation 1. b Aggregation 2. Standard error bars are shown
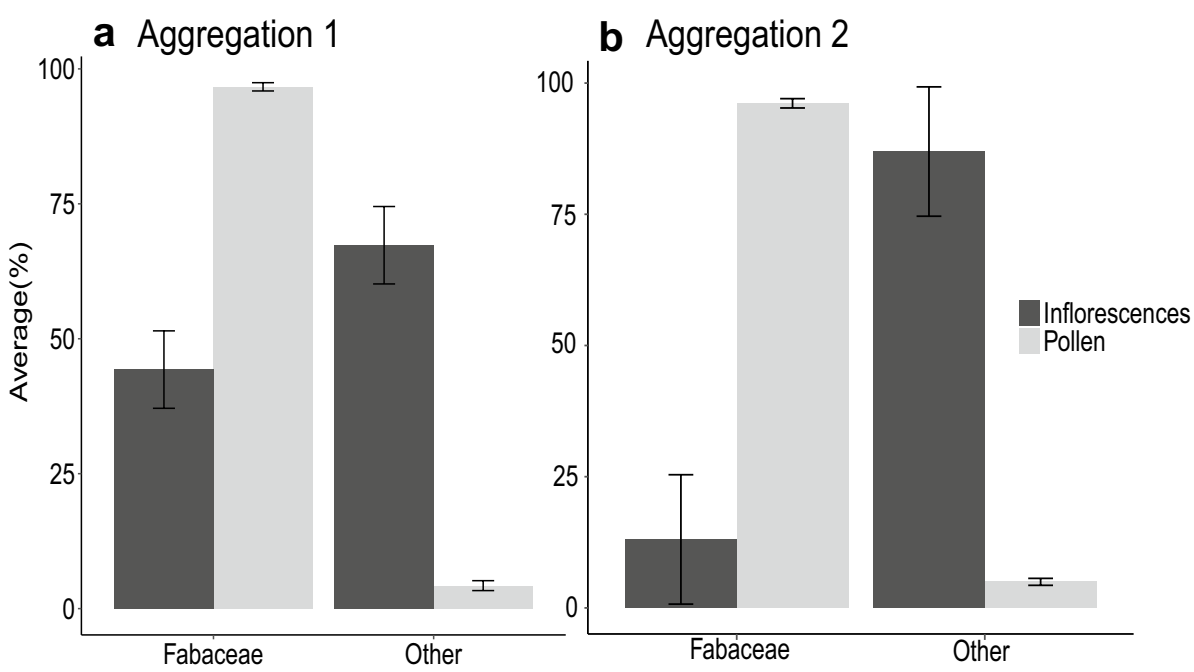
Table 3 Plant groups identified in pollen samples from female E. longicornis for both aggregations for all years. How many samples each group was present in are shown. -Indicates the plant group was not present in any samples that year. *Indicates that when present the species accounted for less than $1 \%$ of the grains in a sample, potentially indicating contamination

\begin{tabular}{|c|c|c|c|c|c|c|}
\hline & \multicolumn{3}{|c|}{ Aggregation 1} & \multicolumn{3}{|c|}{ Aggregation 2} \\
\hline & 2017 & 2018 & 2019 & 2017 & 2018 & 2019 \\
\hline Plant group & $\begin{array}{l}\text { Present on } \\
\mathrm{n} / 19 \text { bees } \\
(\%)\end{array}$ & $\begin{array}{l}\text { Present on } \\
\mathrm{n} / 25 \text { bees } \\
(\%)\end{array}$ & $\begin{array}{l}\text { Present on } \\
\text { n/69 bees } \\
(\%)\end{array}$ & $\begin{array}{l}\text { Present on } \\
\text { n/14 bees } \\
(\%)\end{array}$ & $\begin{array}{l}\text { Present on } \\
\text { n/9 bees } \\
(\%)\end{array}$ & $\begin{array}{l}\text { Present on } \\
\text { n/45 bees } \\
(\%)\end{array}$ \\
\hline Fabaceae & $19 / 19(100)$ & $25 / 25(100)$ & $69 / 69(100)$ & $14 / 14(100)$ & 9/9 (100) & $45 / 45(100)$ \\
\hline Troflium repens & $19 / 19(100)$ & $24 / 25(96)$ & $69 / 69(100)$ & $14 / 14(100)$ & 8/9 (89) & $34 / 45(76)$ \\
\hline Lotus corniculatus & $19 / 19(100)$ & $16 / 25(64)$ & $52 / 69(75)$ & $11 / 14(79)$ & $1 / 9(11)$ & $26 / 45(58)$ \\
\hline Rubus futicosus & $13 / 19(68)$ & $15 / 25(60)$ & $1 / 69(1)$ & - & $7 / 9(78)$ & $5 / 45(11)$ \\
\hline Phacelia tanacetifolia & $3 / 19(16)$ & $3 / 25(12)$ & $1 / 69(1)$ & $2 / 14(14)$ & - & - \\
\hline Asteraceae & $1 / 19(5)^{*}$ & - & $2 / 69(3)^{*}$ & - & - & - \\
\hline Unknown & $1 / 19(5)$ & - & $1 / 69(1)$ & - & - & $7 / 45(16)$ \\
\hline Clematis vitalba & - & - & $3 / 69(4)$ & - & - & $1 / 45(2)^{*}$ \\
\hline Trifolium pratense & - & - & $5 / 69(7)$ & - & - & $1 / 45(2)^{*}$ \\
\hline Silene dioicia & - & - & 2/69 (3) & - & - & \\
\hline Thypha latifola & - & - & $1 / 69(1)^{*}$ & - & - & \\
\hline Filipendula ulmaria & - & - & 1/69 (1) & - & - & \\
\hline
\end{tabular}

with $411 \pm 97.5$ in meadow surveys and low but not zero in woodland $0.13 \pm 28.2$ and managed grassland $0.88 \pm 110$.

The landscape within $100 \mathrm{~m}$ was $73 \%$ meadow and $27 \%$ woodland for aggregation 1 and $28 \%$ meadow, $55 \%$ woodland and $17 \%$ man made (a carpark) for aggregation 2 . Within $500 \mathrm{~m}$ of both aggregations, managed grassland had the greatest area (aggregation 1:36.8\%, aggregation 2:34.2\%, Supplementary Materials Figs. S3 and S4).

During the floral surveys one unmarked female and male were caught. The female was caught approximately $300 \mathrm{~m}$ to the South West of aggregation 2 (51.158382, $-0.199089)$ within the meadow habitat. The male was caught approximately $700 \mathrm{~m}$ to the North East of aggregation 2 (51.161666, -0.189562$)$, also in the meadow habitat. The female was foraging on L. pratensis and the male on $T$. repens.

\section{Discussion}

Eucera longicornis at Gatwick airport is an example of how human intervention and land management can aid wildlife conservation of a rare and endangered species. The two nest aggregations are both in man-made habitats and appear to have stable female populations of reasonable size, so far as this 3-year study can reveal. Aggregation 1, the larger, had estimated female populations of over 400 in 2019 and 380 in 2018, versus 146 and 183 for aggregation 2. Fabaceae species were the main pollen sources for E. longicornis, averaging $95 \%$ of samples. Within $100 \mathrm{~m}$ of the nest aggregations these Fabaceae species were abundant and many were also growing in man-made or altered habitats.

\section{Population estimates}

Estimates appear to indicate that the populations were approximately stable between 2018 and 2019 with both populations smaller in 2017. However, surveys in 2017 were for a much shorter period and did not include male estimates due to starting after the period of male activity. Males emerged before females, with peak population estimates either in late May or early June, compared to middle to late June for females. Earlier emergence of males is common in solitary bees and other insects (Wiklund and Fagerström 1977) and is generally due to mating strategy, with males waiting to mate with newly emerged females.

Both aggregations had female biased sex ratios in 2019, (aggregation 1, 2019 1:3.4; aggregation 2, 2019 1:4.3). In solitary bees, sex ratios have been found to deviate from the predicted Fisherian 1:1 ratio (Rosenheim et al. 1996). These deviations are often due to differences in parental investment for each sex as well as local mate competition and limited egg production (Herre 1985; Rosenheim et al. 1996). Sexual dimorphism is common in Hymenoptera, generally with females being larger (Helms 1994). This is true for E. longicornis, with males on average weighing $0.048 \mathrm{~g}$ compared to a female average of $0.066 \mathrm{~g}$ (Saunders pers. comms.). This results in an expected male bias sex ratio in the population, as males should be less costly to produce. However, when local resource availability is good this can result in investment in the more costly sex to be advantageous (Kim 1999). This is because females can allocate more resources to each individual offspring (Peterson et al. 2006). Perhaps the increase of both female populations 
indicates favourable foraging conditions in the areas surrounding the aggregations.

We are unsure as to why the aggregations in this study have such a high female sex bias, and why this bias was not present in aggregation 1 in 2018. Although local mate competition and inbreeding can cause female bias (Herre 1985), this seems unlikely to be the case with E. longicornis, as mating occurs outside the natal nest and males are seen searching for mates at the nest sites. From a conservation perspective, female bias may be advantageous. The males present would be sufficient to fertilise the females and the larger number of females would boost the number of brood reared, with the effect on effective population size being small (Wright 1993).

In the Hymenoptera the risk with a highly skewed sex ratio in a population is the reduction of the equilibrium number of sex-alleles. However, the population size estimated for E. longicornis at Gatwick appear to be greater (>100) than would give cause for concern in terms of sex alleles and diploid male production in a species with complementary sex determination (Zayed 2004).

It is possible that the biased sex ratio is due to the methods used, with females perhaps easier to capture than males. However, capture probabilities for males were estimated to be higher than for females in 2019. Survival estimates for males in 2019 at both aggregations were lower than in 2018 and lower than the female estimates, with a large reduction in survival for males in aggregation 1 between years $(2018 ; 0.93,2019 ; 0.36)$. We are unsure as to why the estimated survival rate for males was so much lower in 2019 for aggregation 1 . The difference in survival between males and females may be due to males not having a nest to return to either at night or during times of bad weather (Alves-dosSantos et al. 2009). Males also often disperse from the natal nest site (López-Uribe et al. 2015) and if not caught before this time would not be included in the population estimate. Higher mortality or dispersal rate of males could partially explain the female bias sex ratio seen in these populations.

By placing emergence traps and digging up nests and examining cells the true sex and investment ratios could be determined.

\section{Nest site characteristics}

Eucera longicornis tends to nest on south facing, soft banks of bare soil or cliff face in the locations where it is found (Saunders 2014). In agreement with this, both Gatwick aggregations are nesting in sloped banks. Both these nesting sites exist as a result of human intervention. At Gatwick Airport, aggregation 1 is nesting on a manmade raised mound of excavated soil, and aggregation 2 along the bank of the river Mole (Fig. 3). In 1999 Gatwick Airport diverted a section of the river to allow the expansion of the airport's western boundary. A new channel to the west of the old course, plus the shortening of a connecting western tributary, resulted in the river being moved a few hundred meters to the west of the original course. This new channel was altered to meander and allowed the creation of new habitats, such as the meadow along the length of the channel (British Airport Authority 2004). Through the altering of the river, the bank with aggregation 2 was created. Some of the soil excavated during the project was left on Gatwick land to eventually become the heap in which aggregation 1 is located. It is unlikely that $E$. longicornis were present before this land management. This an example of how an industrial/commercial area, such as an airport, can manage the surrounding landscape in such a way as to create habitats and thereby help the conservation of a nationally rare species of wildlife.

Both nest aggregation sites have little vegetation cover and many patches of bare ground, a common characteristic of ground nesting bees (Wuellner 1999; Sardinas and Kremen 2014). Aggregation 1 has not moved from or expanded its nest location since it was first identified in 2014 (Rachel Bicker Pers comms). As of 2018, aggregation 2 has extended $20 \mathrm{~m}$ further along the bank from its original location.

Surveys conducted along the banks of the river Mole and along suitable banks near aggregation 1 as part of this project as well as surveys by the Gatwick biodiversity team, have not discovered additional nest aggregations. Many species of solitary bees exhibit nest philopatry (Yanega 1990; Potts and Willmer 1997) in which newly- emerged females nest at their natal nesting site, instead of leaving to nest elsewhere. This will often have selective value for a foundress, as the natal nest site was successful enough to produce adults in the previous year, and therefore, is likely to be suitable again (Potts and Willmer 1997).

Limited availability of nest sites is also a reason why females may nest in their natal area instead of finding a new site (Batra 1978). However, at Gatwick there appear to be many banks of soft, bare soil, like the ones which already contain aggregations close by at both aggregations $(<10 \mathrm{~m})$. If the female population continues to grow and nest density capacity is reached, dispersal from these aggregations is possible with new aggregations potentially being formed beyond the area surveyed. A male E. longicornis was sighted approximately $1 \mathrm{~km}$ from aggregation 2 (Pers comms. Laurie Wright). This male may be from one of the aggregations in this study, or potentially a new aggregation not identified. Future surveys covering a wider area are required.

\section{Pollen composition}

Pollen collected from returning females from both aggregations was predominantly Fabaceae species which was present in all (113) samples taken from individual females and 
always accounted for more than $90 \%$ of the total grains in a sample. Pollen was identified as Trifolium, Lotus, Lathyrus and Vicia species. The most common non Fabaceae species was bramble, $R$. fruticosus which averaged $5 \%$. This narrow familial range of pollen collection indicates that $E$. longicornis is oligolectic (Mueller and Kuhlmann 2008) and agrees with previous research (Saunders 2014). Visual sightings of males on Symphytum orientale (white comfrey), a species of pollen not identified in female pollen loads, indicates a slightly broader foraging range than for female pollen collection. Differences in male and female foraging preferences are often seen in solitary bee species (Ritchie et al 2016) even in those with a narrow diet breadth. This is most likely due to males not needing to collect pollen for cell provisioning. In addition, male solitary bees normally emerge earlier than females, as seen in this study, so that the floral composition in the area will be slightly different, influencing what species they forage on.

\section{Landscape composition}

Fabaceae pollen sources were most abundant in the meadow habitats (Fig S3, Supplementary Materials) for both aggregations, and within $100 \mathrm{~m}$ of aggregation 1 meadow is the predominant habitat type (72\%). The proximity of the appropriate floral resources to the nesting sites is important as $E$. longicornis is reported to have a foraging range of approximately 500 m (Saunders 2014). An abundance of good quality forage near to the nesting site helps reduce the costs of foraging and therefore potentially increases reproductive output (Zurbuchen et al. 2010a, b).

\section{E. longicornis conservation status}

Eucera longicornis is in decline in Britain and other parts of its range (Pekkarinen 1997; BWARS 2012). In Cornwall, a stronghold for the species, there has been a $55 \%$ reduction since 1987 in the number of sites where it is found, from 24 to 11 (Saunders 2014). This is thought to be due to a combination of the loss of flowering legumes, increased extreme storm events along their coastal sites destroying nests, and a lack of sites containing both early and late flowering legume species such as Anthyllis vulneraria and Lathyrus sylvestris (Saunders 2017). Fabaceae species often occur in flower rich grasslands, which are declining in the UK (Goulson et al. 2005). This is due to a variety of factors, predominantly changes in agricultural practices. Between early and late twentieth century, fodder crops declined by more than $55 \%$ and were replaced with permanent grassland (Ollerton et al. 2014). These changes in landscape management have resulted in both a reduction in the range of many of the pollen sources E. longicornis rely on, as well as their frequency at a more local scale. For example, L. pratensis, a major pollen source for E. longicornis, reduced in frequency by 45\% in the UK between 1978 and 1998 (Carvell et al. 2006). Owing to airports often having semi-natural grasslands surrounding runways, they have the potential to provide this much declining habitat which contains the floral resources that E. longicornis and other species need.

\section{Management plans and future research}

Although not known for their wildlife value or biodiversity, if managed correctly airports can provide a refuge for some species, as seen with E. longicornis at Gatwick. Another example is the presence of rare ground nesting birds at John F. Kennedy (JFK) airport in New York City, USA. The upland sand piper, grasshopper sparrow, and horned lark have all been found nesting in the airports semi-natural grassland habitat (Chevalier and Cohen 1997; Kershner and Bollinger 1996). A high abundance and diversity of arthropod species have also been identified at JFK (KutschbachBrohl et al. 2010), highlighting that if managed correctly airports have the potential to benefit wildlife.

There are over 60 major airports in the UK (Civil Aviation Authority 2020) and with the growing demand for airline travel the size and demand on airports is likely to increase (Upham et al. 2003). This highlights the importance of surveying airport land for wildlife and ensuring the land is managed effectively. Currently, Gatwick Airport's management of the study area involves a single September cut of the meadow around the two aggregations, and coppicing of the woodland to help create and maintain compartments for wildflowers (Rachel Bicker Pers comms.), which should be continued. Ensuring the woodland surrounding the aggregations does not begin to encroach on the meadowland is also essential (Table 4).

Continued monitoring of the aggregations is recommended and, hopefully, to confirm that the existing management is effective. The mark recapture method used in this study is highly intensive and therefore, is likely to be impractical for future monitoring of population sizes unless additional staff are recruited. However, the population can be monitored in other ways. Counts along transect routes, recording number of nest holes at each aggregation site, and fixed standardised counts of activity at the aggregations are all potential population monitoring methods. For further information on management and monitoring suggestions see Table 4. These latter methods require less training but can still give a quantitative measure of population size (Bischoff 2003; Larsson and Franzen 2008) that could be compared across years to quantify any trends or changes. From what we can see from the current management and situation, it appears the two aggregations at Gatwick Airport are not threatened. Both have additional unused nesting space nearby and abundant forage and both foraging and 


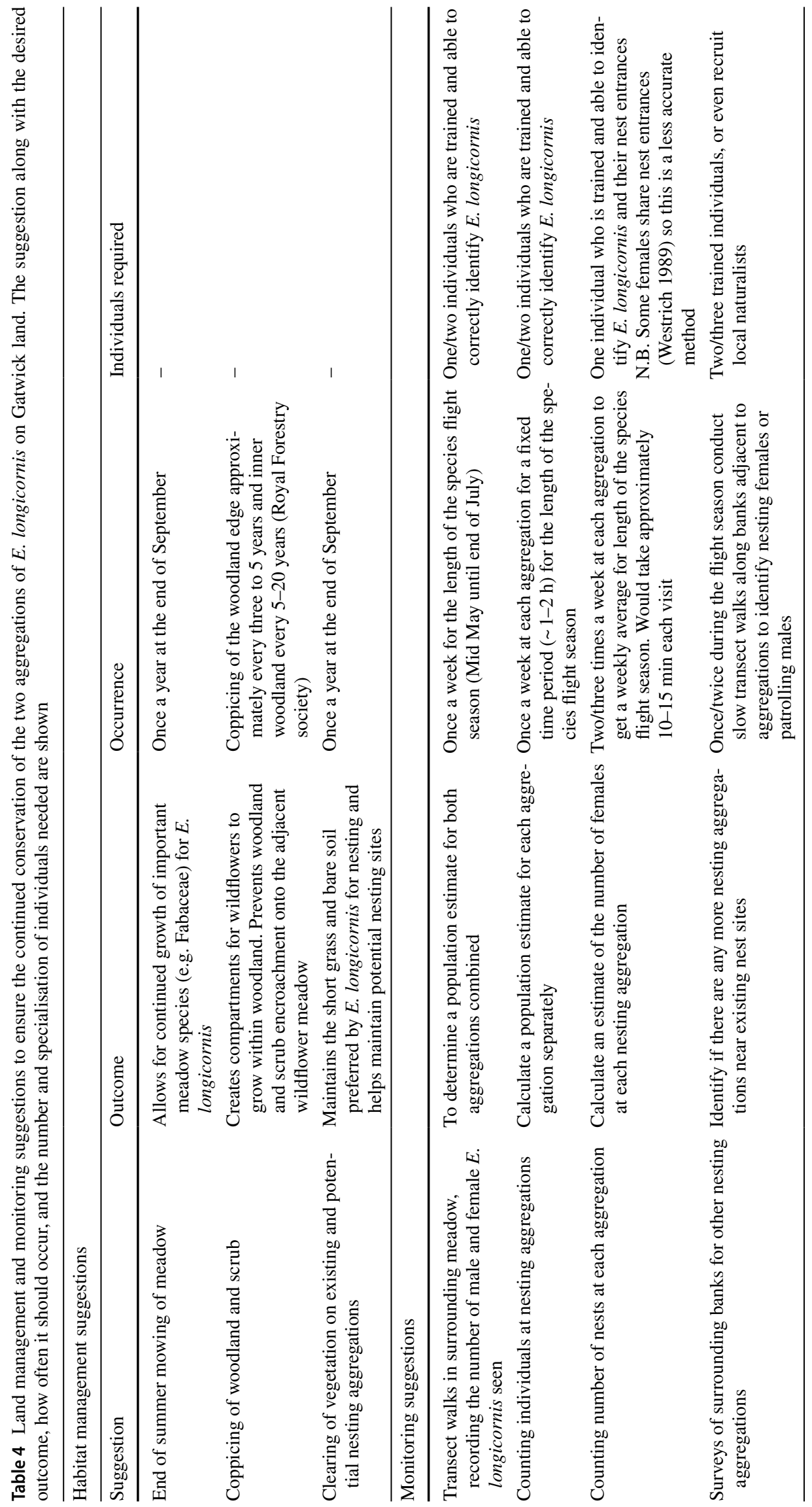


nesting location are not in danger of becoming unsuitable either from natural or human factors.

Future work on these aggregations could consist of surveys of the surrounding soil banks, which are currently not being used as nesting sites, to determine if new nesting aggregations are founded. E. longicornis is also a key candidate for citizen science due to the males distinctive and unusual appearance, with their long antennae unlike any other native bees to the UK. This would make is possible to carry out a large-scale survey of the surrounding area using information from local residents. In 2018 a male was recorded approximately $3 \mathrm{~km}$ South East of the existing aggregations (NBN atlas 2018), perhaps indicating more nesting sites in the local area.

In many cases human changes to the landscape are detrimental to species and biodiversity (Winfree et al. 2011; Senapathi et al. 2015). However, through effective management biodiversity can be maintained and some species can even thrive in these human-altered landscapes (Macadam and Bairner 2012; Sirohi et al. 2015). Although E. longicornis is in decline throughout its range, by monitoring and conserving small populations like those at Gatwick, the conservation of this charismatic species may be possible.

Acknowledgements We would like to thank Gatwick Airport for funding and allowing access to airport owned land. We would especially like to thank Rachel Bicker, Gatwick Airports biodiversity officer, for all her help and support and the invaluable information she provided. Thank you also to Sussex University Doctoral school for joint funding this research.

Funding GH was funded by Gatwick Airport and the University of Sussex Doctoral School.

\section{Compliance with ethical standards}

Conflict of interest The authors declare that they have no competing interests.

Ethical approval Due to the study system being invertebrates and no destructive sampling was used ethical approval was not required.

Open Access This article is licensed under a Creative Commons Attribution 4.0 International License, which permits use, sharing, adaptation, distribution and reproduction in any medium or format, as long as you give appropriate credit to the original author(s) and the source, provide a link to the Creative Commons licence, and indicate if changes were made. The images or other third party material in this article are included in the article's Creative Commons licence, unless indicated otherwise in a credit line to the material. If material is not included in the article's Creative Commons licence and your intended use is not permitted by statutory regulation or exceeds the permitted use, you will need to obtain permission directly from the copyright holder. To view a copy of this licence, visit http://creativecommons.org/licenses/by/4.0/.

\section{References}

Ahrne K, Bengtsson J, Elmqvist T (2009) Bumble bees (Bombus spp) along a gradient of increasing urbanization. PLoS ONE. https:// doi.org/10.1371/journal.pone.0005574

Alves-dos-Santos I, Gaglianone MC, Naxara SRC, Engel MS (2009) Male sleeping aggregations of solitary oil-collecting bees in Brazil (Centridini, Tapinotaspidini, and Tetrapediini; Hymenoptera: Apidae). Genet Mol Res 8:515-524

Banaszak-Cibicka W, Żmihorski M (2012) Wild bees along an urban gradient: winners and losers. J Insect Conserv 16:331-343

Baldock K, Goddard MA, Kunin WE, Potts SG, Stone GN, Memmott J (2015) Managing urban areas for insect pollinators: As town and cities continue to grow how can land managers help insect pollinators in urban areas? https://research-informatio n.bris.ac.uk/files/52299185/LWEC_20_PPN.pdf. Accessed 2 March 2020

Batra SW (1978) Aggression, territoriality, mating and nest aggregation of some solitary bees (Hymenoptera: Halictidae, Megachilidae, Colletidae, Anthophoridae). J Kansas Entomol Soc 51:547-559

Bischoff I (2003) Population dynamics of the solitary digger bee Andrena vaga Panzer (Hymenoptera, Andrenidae) studied using mark-recapture and nest counts. Popul Ecol 45:197-204

British Airport Authority (2004) River mole diversion fish monitoring Buglife (2009) Planning for brownfield biodiversity: a best practice guide. Buglife-The Invertebrate Conservation Trust, Peterborough

Burnham KP, Anderson DR (1998) Practical use of the informationtheoretic approach. In: Burnham KP, Anderson DR (eds) Model selection and inference. Springer, New York, pp 75-117

BWARS (2012) Eucera longicornis. https://www.bwars.com/bee/apida e/eucera-longicornis. Accessed 1 Feb 2020

Carvell C, Roy DB, Smart SM, Pywell RF, Preston CD, Goulson D (2006) Declines in forage availability for bumblebees at a national scale. Biol Conserv 132:481-489

Chevalier S, Cohen JR (1997) Twenty-eight year study of upland sandpiper breeding population. https://sora.unm.edu/sites/default/files /journals/nabb/v022n03/p0109-p0113.pdf. Accessed 4 Mar 2020

Civil Aviation Authority (2020) UK airport data. https://www.caa. co.uk/Data-and-analysis/UK-aviation-market/Airports/Datasets/ UK-airport-data/. Accessed 30 April 2020

Cooch EG, \& White GC (2004) Program MARK: analysis of data from marked individuals. A gentle introduction. Available at http://www.phidot.org/software/mark/docs/book/. Accessed 24 Aug 2020

Didham RK, Basset Y, Collins CM, Leather SR et al (2020) Interpreting insect declines: seven challenges and a way forward. Insect Conserv Divers 13:103-114

Falk S, Lewington R (2015) Field guide to the bees of Great Britain and Ireland. Bloomsbury Publishing, London

Formstone B, Howe M (2013) Brownfield sites and their value for invertebrates-A survey of selected sand quarries in north-east. Borras Quarry and Marford Quarry, Wales

Gathmann A, Tscharntke T (2002) Foraging ranges of solitary bees. J Anim Ecol 71:757-764

Goulson D, Hanley ME, Darvill B, Ellis JS, Knight ME (2005) Causes of rarity in bumblebees. Biol Conserv 122:1-8

Goulson D, Lye GC, Darvill B (2008) Decline and conservation of bumble bees. Annu Rev Entomol 53:191-208

Greenleaf SS, Williams NM, Winfree R, Kremen C (2007) Bee foraging ranges and their relationship to body size. Oecologia 153:589-596

Helms KR (1994) Sexual size dimorphism and sex ratios in bees and wasps. Am Nat 143:418-434 
Herre EA (1985) Sex ratio adjustment in fig wasps. Science 228:896-898

JNCC (2007) UK Biodiversity Action Plan, Terrestrial Invertebrates. https://data.jncc.gov.uk/data/98fb6dab-13ae-470d-884b-7816a fce42d4/UKBAP-priority-terrestrial-invertebrates.pdf. Accessed 29 April 2020

Kershner EL, Bollinger EK (1996) Reproductive success of grassland birds at east-central Illinois airports. Am Midl Nat 136:358-366

Kim JY (1999) Influence of resource level on maternal investment in a leaf-cutter bee (Hymenoptera: Megachilidae). Behav Ecol 10:552-556

Kutschbach-Brohl L, Washburn BE, Bernhardt GE, Chipman RB, Francoeur LC (2010) Arthropods of a semi-natural grassland in an urban environment: the John F. Kennedy International Airport New York. J Insect Conserv 14:347-358

Larsson M, Franzen M (2008) Estimating the population size of specialised solitary bees. Ecol Entomol 33:232-238

Leather SR (2017) "Ecological Armageddon"-more evidence for the drastic decline in insect numbers. Ann Appl Biol 172:1-3

López-Uribe MM, Morreale SJ, Santiago CK, Danforth BN (2015) Nest suitability, fine-scale population structure and male-mediated dispersal of a solitary ground nesting bee in an urban landscape. PLoS ONE. https://doi.org/10.1371/journal.pone.0125719

Macadam CR, \& Bairner SZ (2012) Urban biodiversity: successes and challenges: Brownfields: Oases of urban biodiversity. The Glasgow Naturalist, 25(4). Retrieved from http://www.glasgownat uralhistory.org.uk. Accessed 24 August 2020

Montgomery GA, Dunn RR, Fox R, Jongejans E, Leather SR, Saunders ME, Shorthall CR, Tingley MW, Wagner DL (2020) Is the insect apocalypse upon us? How to find out. Biol Conserv 241:108327

Mueller A, Kuhlmann M (2008) Pollen hosts of western palaearctic bees of the genus Colletes (Hymenoptera: Colletidae): the Asteraceae paradox. Biol J Linn Soc 95:719-733

NBN atlas occurrence download at https://spatial.nbnatlas. org/?q=1sid:NHMSYS0000875930-NBN. Accessed 30 Mar 2020

Pekkarinen A (1997) Oligolectic bee species in northern Europe (Hymenoptera, Apoidea). Entomol Fennica 8:205-214

Peterson JH, Roitberg BD, Peterson JH (2006) Impacts of flight distance on sex ratio and resource allocation to offspring in the leafcutter bee, Megachile rotundata. Behav Ecol Sociobiol 59:589-596

Potts S, Willmer PAT (1997) Abiotic and biotic factors influencing nest-site selection by Halictus rubicundus, a ground-nesting halictine bee. Ecol Entomol 22:319-328

Powney GD, Carvell C, Edwards M, Morris RK, Roy HE, Woodcock BA, Isaac NJ (2019) Widespread losses of pollinating insects in Britain. Nat Commun 10:1-6

Ollerton J, Erenler H, Edwards M, Crockett R (2014) Extinctions of aculeate pollinators in Britain and the role of large-scale agricultural changes. Science 346:1360-1362

R Core Team (2017) R: A language and environment for statistical computing. R Foundation for Statistical Computing, Vienna, Austria. https://www.R-project.org/.

Rasmont P, Franzén M, Lecocq T, Harpke A et al (2015) Climatic risk and distribution atlas of European bumblebees. Pensoft Publishers 10:1-236

Ritchie AD, Ruppel R, Jha S (2016) Generalist behaviour describes pollen foraging for perceived oligolectic and polylectic bees. Environ Entomol 45:909-919

Rosenheim JA, Nonacs P, Mangel M (1996) Sex ratios and multifaceted parental investment. Amm Nat 148:501-535
Sardinas HS, Kremen C (2014) Evaluating nesting microhabitat for ground-nesting bees using emergence traps. Basic Appl Ecol 15:161-168

Saunders P (2014) Eucera longicornis, The long horned mining bee in Cornwall. Available at http://kernowecology.co.uk/Publications/ eucera\%20article.pdf. Accessed 24 Aug 2020

Saunders P (2017) The long horned bee in Cornwall. https://kerno wecology.co.uk/Publications/Long\%2520horn\%2520bee\%2520p s\%25202017.pdf. Accessed 1 Jan 2020

Sawyer R, Pickard RS (1981) Pollen identification for beekeepers. University College Cardiff Press, Cardiff

Scriven LA, Sweet MJ, Port GR (2013) Flower density is more important than habitat type for increasing flower visiting insect diversity. Int J Ecol. https://doi.org/10.1155/2013/237457

Senapathi D, Carvalheiro LG, Biesmeijer JC, Dodson CA et al (2015) The impact of over 80 years of land cover changes on bee and wasp pollinator communities in England. Proc R Soc B 282:20150294

Sirohi MH, Jackson J, Edwards M, Ollerton J (2015) Diversity and abundance of solitary and primitively eusocial bees in an urban centre: a case study from Northampton (England). J Insect Conserv 19:487-500

Steinert M, Sydenham MAK, Eldegard K, Moe SR (2020) Conservation of solitary bees in power-line clearings: sustained increase in habitat quality through woody debris removal. Glob Ecol Conserv 21:e00823. https://doi.org/10.1016/j.gecco.2019.e00823

Svirejeva-Hopkins A, Schellnhuber HJ, Pomaz VL (2004) Urbanised territories as a specific component of the global carbon cycle. Ecol Model 173:295-312

Thomas CD, Jones TH, Hartley SE (2019) "Insectageddon": a call for more robust data and rigorous analyses. Glob Change Biol 25:1891-1892

Upham P, Thomas C, Gillingwater D, Raper D (2003) Environmental capacity and airport operations: current issues and future prospects. J Air Transp Manage 9:145-151

Van Dyck H, Van Strien AJ, Maes D, Van Swaay CA (2009) Declines in common, widespread butterflies in a landscape under intense human use. Conserv Biol 23:957-965

Warren MS, Hill JK, Thomas JA, Asher J, Fox R et al (2001) Rapid responses of British butterflies to opposing forces of climate and habitat change. Nature 414:65-69

Wcislo WT, Cane JH (1996) Floral resource utilization by solitary bees (Hymenoptera: Apoidea) and exploitation of their stored foods by natural enemies. Ann Rev Entomol 41:257-286

Westrich P (1996) Habitat requirements of central European bees and the problems of partial habitats. Linn Soc Symp Ser 18:1-16

Wiklund C, Fagerström T (1977) Why do males emerge before females? Oecologia 31:153-158

Winfree R, Bartomeus I, Cariveau DP (2011) Native pollinators in anthropogenic habitats. Ann Rev Ecol Evol Syst 42:1-22

Wood TJ, Holland JM, Goulson D (2017) Providing foraging resources for solitary bees on farmland: current schemes for pollinators benefit a limited suite of species. J App Ecol 54:323-333

Wright S (1933) Inbreeding and homozygosis. Proc Natl Acad Sci USA 19:411-420

Wuellner CT (1999) Nest site preference and success in a gregarious, ground-nesting bee Dieunomia triangulifera. Ecol Entomol 24:471-479

Yanega D (1990) Philopatry and nest founding in a primitively social bee Halictus rubicundus. Behav Ecol Sociobiol 27:37-42

Zanette LRS, Martins RP, Ribeiro SP (2005) Effects of urbanization on Neotropical wasp and bee assemblages in a Brazilian metropolis. Landsc Urban Plan 71:105-121 
Zayed A (2004) Effective population size in Hymenoptera with complementary sex determination. Heredity 93:627-630

Zurbuchen A, Landert L, Klaiber J, Müller A, Hein S, Dorn S (2010) Maximum foraging ranges in solitary bees: only few individuals have the capability to cover long foraging distances. Biol Conserv 143:669-676
Zurbuchen A, Cheesman S, Klaiber J, Müller A, Hein S, Dorn S (2010) Long foraging distances impose high costs on offspring production in solitary bees. J Anim Ecol 79:674-681

Publisher's Note Springer Nature remains neutral with regard to jurisdictional claims in published maps and institutional affiliations. 